


\title{
BUSH FRUITS IN EASTERN CANADA
}

\author{
By \\ D. S. Blair \\ DIVISION OF HORTICULTURE \\ EXPERIMENTAL FARMS SER VICE
}

M. B. DAVIS

Dominion Horticulturist

Published by authority of the Right Honourable James G. Gardiner, Minister of Agriculture, Ottawa, Canada 
Digitized by the Internet Archive in 2012 with funding from

Agriculture and Agri-Food Canada - Agriculture et Agroalimentaire Canada

http://www.archive.org/details/bushfruitsineast00blai 


\section{CONTENTS}

RASPBERRY CULTURE PAGE

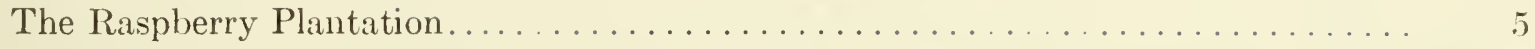

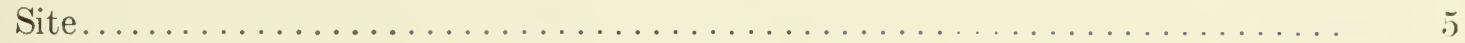

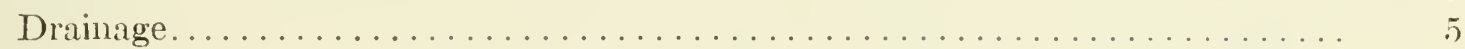

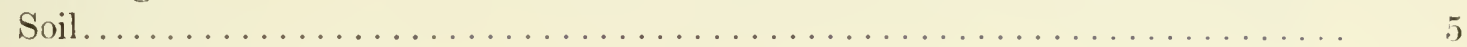

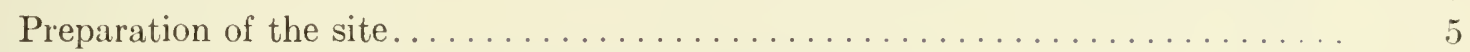

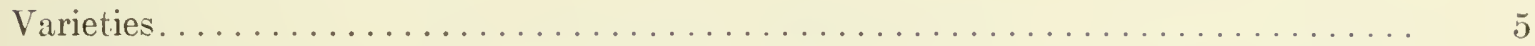

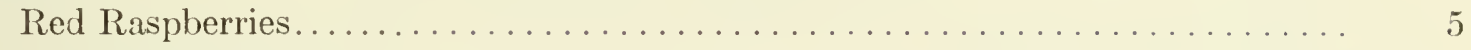

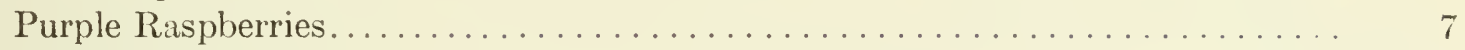

Black Raspberries.................................... 8

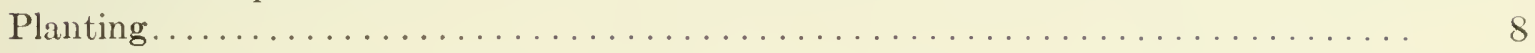

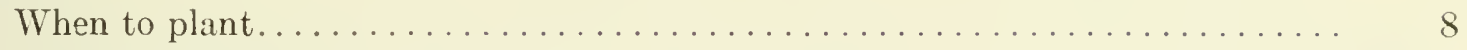

Systems of planting....................................... 8

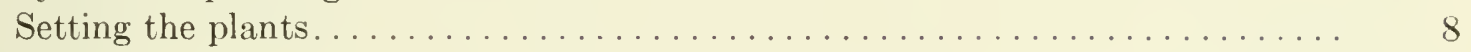

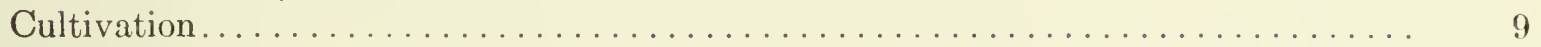

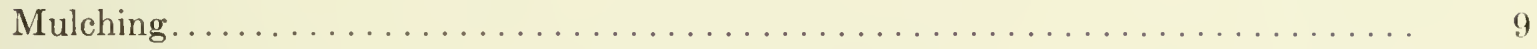

Fertilizers......................................... 9

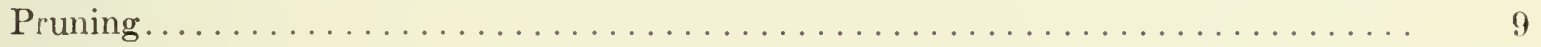

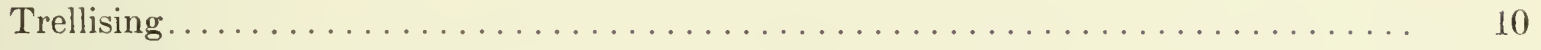

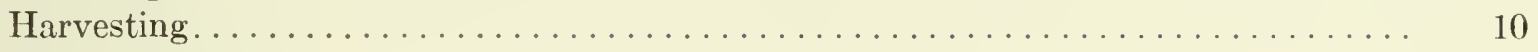

Winter Protection......................................... 10

\section{BLACKBERRY CULTURE}

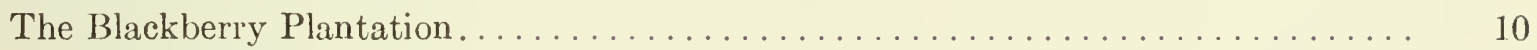

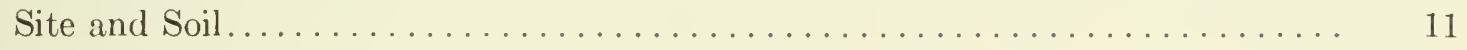

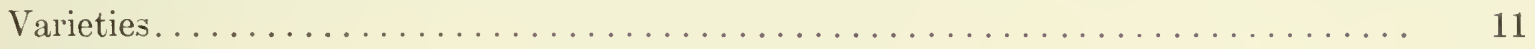

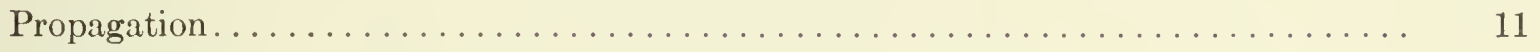

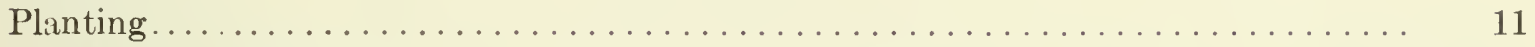

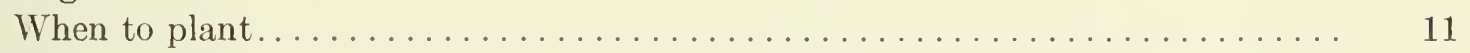

How to plant.............................................. 11

Cultivation................................................ ${ }_{11}$

Fertilizers......................................... 12

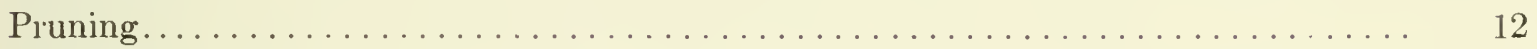

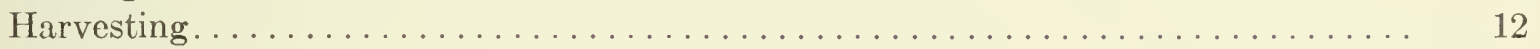

Winter Protection........................................... 12

\section{GOOSEBERRY CULTURE}

The Gooseberry Plantation ................................. 13

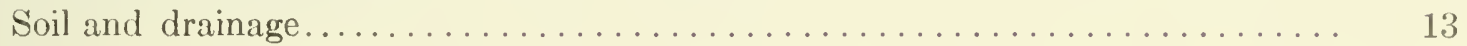

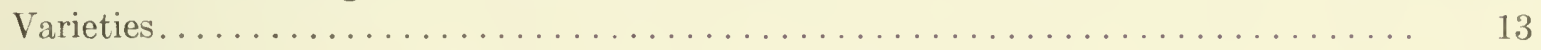

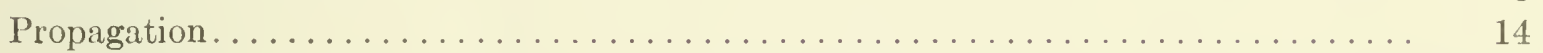

Layering......................................... 14

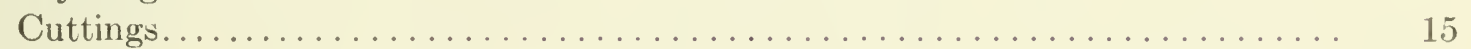

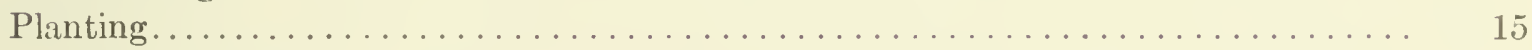

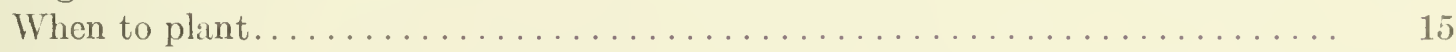

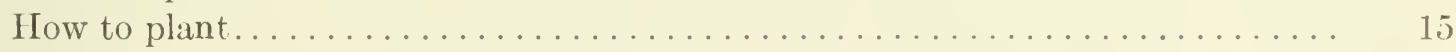

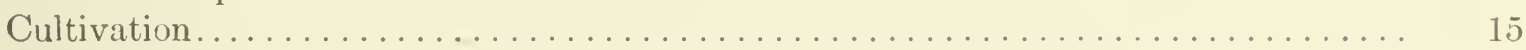

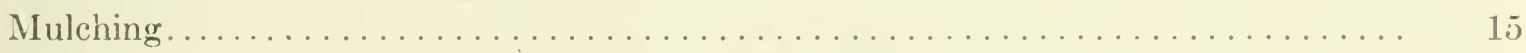

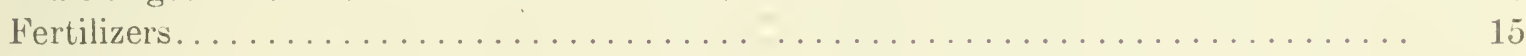

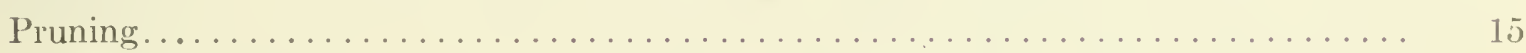

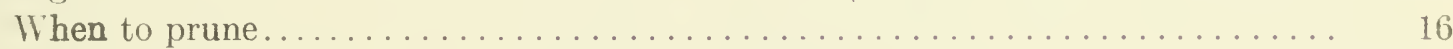

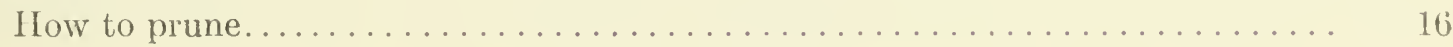


CONTENTS-Concluded

CLIRRANT CULTURE PAUE

The Currant Plantation.................................. 16

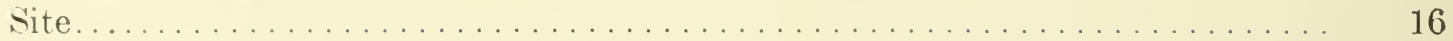

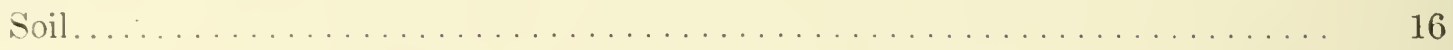

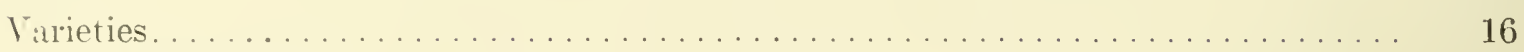

Black Currants.......................................... 17

Red Currants.......................................... 17

White Currants..................................... 18

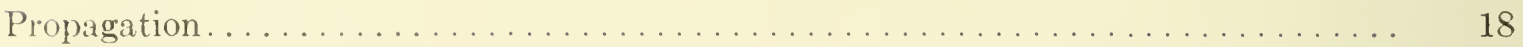

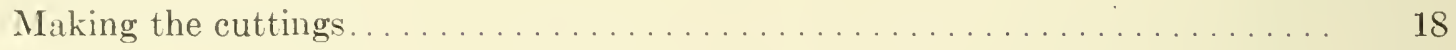

Care of the cuttings................................... 18

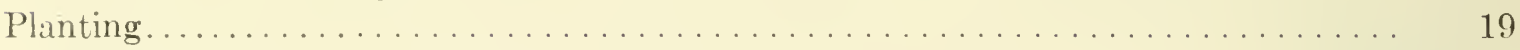

When to plant........................................... 19

How to plant. . . . . . . . . . . . . . . . . . . . . . . . . . . . . 19

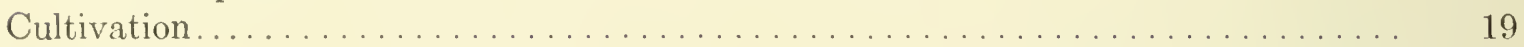

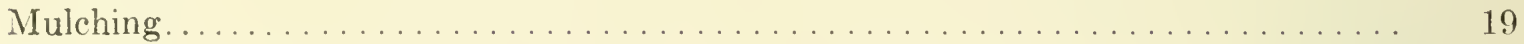

Fertilizers. . . . . . . . . . . . . . . . . . . . . . . . . . . . . . . . 19

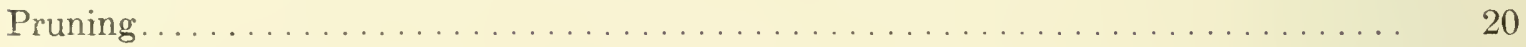

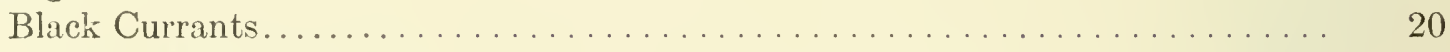

Red and White Currants..................................... 20

BOYSENBERRY CULTURE........................... 20 


\section{RASPBERRY CULTURE}

The raspberry is found growing wild over the entire breadth of Canada and as far north as the Mackenzie River delta. This fact indicates that it can be cultivated successfully in every province and in many northern areas of the country.

\section{The Raspberry Plantation}

Site.-Give the raspberry plantation the best location on your property for two reasons: (1) the returns from a heavy yielding plantation are high and (2) the land will be occupied continuously for from six to eight years.

Drainage.-Good drainage, both at the surface and underneath, is absolutely essential. The roots of the raspberry extend downward for about three feet, hence the level of the water-table should be at least that distance from the surface. While good drainage is essential the raspberry also requires a good supply of moisture, especially during the fruiting period. For this reason the soil should be well supplied with humus and consequently retentive of moisture.

Soil.-The best soil is a deep, rich, sandy loam, well supplied with humus. However, both lighter and heavier soils are capable of producing profitable crops.

Preparation of the site.-Because of the long life of the raspberry plantation, prepare the soil thoroughly before planting. If the soil is lacking in humus grow a green manure crop in advance of planting. Completely eradicate weeds that are spread by running roots-couch grass and sow thistle, for example.

\section{Varieties}

The two outstanding red varieties are Viking and Latham. Of these, the former has fruit of superior excellence but lacks somewhat the hardiness of Latham, which, nevertheless, is a highly regarded fruit. Their shipping qualities are about equal. Among the newer red introductions Madawaska, Muskoka, Ottawa, Rideau, Trent, and Tweed merit being widely tested.

Columbia is one of the best of the commercial purple varieties while Cumberland and Plum Farmer are the best blacks. There are several outstanding new black and purple varieties on the market that are superior to Columbia and Plum Farmer and that should be planted in preference to the older varieties when plants are obtainable. Bristol, Dundee, and Naples are the best of the new blacks and Sodus and Marion the pick of the purples.

\section{Red Raspberries}

Gatineau (0-276) (Lloyd George $\times$ Newman 23).-Orig. C.E.F., Ottawa. The fruit is large, round, dark red, medium firm and of good quality. The plants are fairly vigorous and hardy, moderately productive and throw up plenty of suckers. They are rather susceptible to anthracnose and spur blight, but quite resistant to mosaic and apparently free from foliage diseases. Gatineau is outstanding among the early ripening varieties at Ottawa. It has been extensively tested and because of its earliness appears to offer good commercial possibilities in the Ottawa district, and to a lesser degree in western Ontario. It comes in several days ahead of Viking and at least a week before Latham. However, where earliness is not of primary importance, its dark colour and the fact that it is not too firm have militated against it. 
Lathan $($ King $\times$ Loudon).-Orig. Minn. Agr. Exp. Sta., St. Paul, Minn. The fruit is large, round, bright red, attractive, fairly firm but inclined to crumble, and of medium quality. The plants are vigorous, upright, hardy, very productive, and sucker freely. Like Viking, Latham is widely grown in Canada, and is popular largely because of its productivity. Its hardiness makes it particularly suited for culture in the colder regions.

Madawaska (0-272) (Lloyd George $\times$ Newman 23).-Orig. C.E.F., Ottawa. The fruit is large, deep red, medium firm, a bit crumbly if not picked carefully, and of good quality. The plants are hardy, productive, vigorous, have many spines, and send up plenty of suckers. Madawaska is susceptible to anthracnose and spur blight, but quite resistant to mosaic and not affected by foliage diseases. It has about the same season as Trent and gives a good yield in the first week of the picking season. This variety is of real interest because of its extreme hardiness and because of its suitability for canning and jam making. Extensive trials indicate that it is well adapted to most of the raspberry growing districts in Canada. It should be widely tested, especially in the colder regions.

Marcy (Newman $23 \times$ Lloyd George).-Orig. N.Y. State Agr. Exp. Sta., Geneva, N.Y. The fruit is very large, (the largest red raspberry ever grown at Ottawa), conic, glossy dark red, has large druplets, is likely to crumble if not picked carefully, and is fairly firm and of good quality. The plants are vigorous, stout, productive, moderately hardy, and form plenty of suckers. Marcy kills back some at Ottawa, and appears reasonably free from mosaic. Because of its large size, good quality and freedom from disease, this variety is of particular value for the home garden.

Muskoka (0-201) (Newman $23 \times$ Herbert).-Orig. C.E.F., Ottawa. The fruit is large, round, bright red, attractive, has a large core, and is medium firm and of good quality. The plants are moderately vigorous, sucker freely, and are very hardy and productive. This variety is particularly outstanding because of its hardiness, and it is worthy of extensive trial in regions where very low winter temperatures prevail.

Newburgh (Herbert $\times$ Newman 23).-Orig. N.Y. State Agr. Exp. Sta., Geneva, N.Y. The fruit is very large, round, bright red with a heavy white bloom that often gives it a dull appearance, firm and of good quality. The plants are of medium height, branching, productive, often need support, throw up numerous suckers and appear to be quite resistant to mosaic. The large size and firmness of the berries, together with the productiveness of the canes, make this variety worthy of trial. Like Viking it kills back considerably during some winters.

OtтаwA (0-275) (Viking $\times$ (Loganberry $\times$ St. Regis)).-Orig. C.E.F., Ottawa. The fruit is large, round, bright red, attractive, very compact, firm and of good quality but some what hairy. It resembles Viking in appearance but stands up better in shipping. The plants are vigorous, sturdy, have few spines, are resistant to anthracnose and spur blight but susceptible to powdery mildew and late yellow rust and may take mosaic. Favourable reports on this variety have been received from British Columbia, the Ottawa and Niagara districts, the Niaritime Provinces, and the northern United States. It appears to withstand dry conditions better than most varieties, probably because it sends up fewer suckers. It ripens at about the same time as Viking and because of its shipping qualities should be given a trial.

Rideau (0-262) (Iloyd George $\times$ Newman 23).--Orig. C.E.F., Ottawa. The fruit is large, long conic, bright red, attractive, firm and of good quality. It picks easily and drops when overripe. The plants are vigorous, upright, and productive. Rideau has about the same fruiting season and degree of hardiness 
as Viking, killing back considerably during some winters. It is susceptible to anthracnose and spur blight, but quite resistant to mosaic and free from foliage diseases. Rideau appears to be a very heavy feeder and to do better on the lighter, richer soils. Where conditions are farourable on the prairies (where it is given winter protection), in Ontario, in the Maritime Provinces, and in the northern United States, Rideau has been enthusiastically received as a berry for the fresh fruit trade.

Taylor (Newman $23 \times$ Lloyd George).-Orig. N.Y. State Agr. Exp. Sta., Geneva, N.Y. The fruit is large, long conic, bright red, attractive, firm and of good quality. It ripens with or later than Latham. The plants are vigorous, upright, not so hardy as Latham at Ottawa, and susceptible to mosaic. Taylor is worthy of trial because of its outstanding shipping qualities.

Trent (0-264) (Newman $23 \times$ Lloyd George).-Orig. C.E.F., Ottawa. The fruit is large, round, bright red, attractive, medium firm, and of good quality. The plants are fairly vigorous, hardy, produce many suckers, and are very productive. Trent is rather susceptible to anthracnose and spur blight but apparently entirely resistant to mosaic and foliage diseases. The fruiting season is two or three days later than that of Gatineau. Trent ripens with or a full picking ahead of Viking but vields much more than Viking during the first week of the season. In addition it is a heavy yielder of bright, very attractive berries. The brightness and earliness of this berry are attracting favourable attention in British Columbia, Ontario and the Maritime Provinces, and the variety is worthy of extensive trial.

Tweed (0-263) (Newman $23 \times$ Lloyd George).-Orig. C.E.F., Ottawa. The fruit is large, round, rather dark, attractive, firm, and of good quality. The plants are medium vigorous, sucker freely, and are very hardy and productive. At Ottawa, Tweed is the outstanding early variety, outyielding all other varieties in the first week of the picking season. Because of its extreme earliness, productivity, and hardiness it should be widely tested.

Vrking (Cuthbert $\times$ Marlboro).-Orig. Horticultural Experiment Station, Vineland Station, Ontario. The fruit is large, conic, bright lively red, attractive, medium firm, and of very good quality. The plants are vigorous, tall, stout, upright, produce plenty of suckers, are productive and almost free from spines. Viking lacks somewhat the hardiness of Latham and in certain winters the plants kill back considerably at Ottawa. Because of its quality and attractive berries, Viking is the most widely grown red raspberry in Central Canada today.

\section{Purple Raspberries}

While the purple raspberries are not very popular for eating raw, they are excellent for canning or for mixing with the red to give more acidity.

Columbia (a seedling of Cuthbert, probably pollenized by Grerg.).-Orig. J. T. Thompson, Oneida, N. Y., 1888. Introduced about 1894 . The fruit is large, roundish conical, dark purpish-red, firm, moderately juicy, briskly sub-acid, and of good flavour and quality. The season is late. The plants are vigorous, non-suckering, very productive, but none too hardy.

Marion (Bristol $\times$ Geneva No. 2585 (red raspberry seedling)).-Orig. N.Y. State Agr. Exp. Sta., Geneva, N.Y., and introduced in 1937. The fruit is very larga, purple, firm, quite juicy, tart, and of good quality. It ripens about a weok later than Sodus. 'The plants are vigorous, non-suckering, and productive. Like Sodus this variety kills back considerably during some winters. It appears to be fairly free from mosaic, but at the Vineland Station goes down with blue stem. Marion is a large, late berry that follows Sodus and should be tested. 
Sodts (Dundee $\times$ Newburgh).-Orig. N.Y. State Agr. Exp. Sta., Geneva, N.I. The fruit is very large, medium purple, firm, sprightly in flavour and of good quality. The plants are non-suckering, productive, stand up to mosaic much better than Columbia, are very vigorous, but kill back badly during some winters. At the Horticultural Experiment Station, Vineland Station, Ontario, Sodus goes down badly with blue stem. Because of its productiveness, large fruit, and apparent resistance to mosaic it is worthy of trial.

\section{Black Raspberries}

Comberland (thought to be a seedling of Gregg).-Orig. David Miller, Harrisburg, Pa., and introduced in 1896. The fruit is large, black, firm, juicy, sweet in flavour and of good quality. The season is medium early to late. The plants are vigorous, fairly hardy, and productive, but susceptible to virus disease.

Plum Farmer.-Orig. in Ohio and introduced by L. J. Farmel, Pulaski, N.Y., 1895. The fruit is large, black but with a bloom rather than glossy like some varieties, firm, juicy, sub-acid to mild, and of good quality. The season is early to mid season. The plants are vigorous, hardy, and productive.

Bristol---Orig. N.Y. State Agr. Exp. Sta. Geneva, N.Y. The fruit is large, firm, attractive, glossy black, and of very good quality. The plants are vigorous, very productive, and hardy. Because of its earliness and high quality, this variety is worthy of extensive trial.

Dundee.-Orig. N.Y. State Agr. Exp. Sta., Geneva, N.Y. The fruit is large, glossy black, attractive, moderately firm, mildly sub-acid and of very good quality. The plants are tall, vigorous, productive and moderately resistant to mosaic. Dundee has quality and should be widely tested.

Naples.-Orig. N.Y. State Agr. Exp. Sta., Geneva, N.Y. The fruit is large, attractive, glossy black, firm, and of good quality. The plants are vigorous, productive, fairly haldy, and appear resistant to anthracnose. Naples is promising as a late variety.

\section{Planting}

When to plant.-Plant in the very early spring, in the fall during the month of September, or even as late as the middle of October. In Central Canada fall planting is recommended.

Systems of planting.-Red raspberries are usually grown in the hedge-row system. Set the plants in rows seven or eight feet apart with two or three feet between the plants in the rows. Allow the suckers to fill the row until a complete hedge-row of canes, one or two feet wide, is obtained.

Purple or black raspberries are usually grown in the hill system, as they are non-suckering. Set the plants five or six feet apart each way.

Setting the plants.-Cut back the canes to a height of six inches before setting, and place them about the same depth as, or slightly deeper than, they grew previously.

The most common method of setting is as follows: (a) furrow out the row with a plough, (b) place the plants against the side of the furrow, (c) partially cover the roots by hand, (d) firmly tramp the soil around the roots, and (e) completely cover the roots with the plough.

Setting may also be done by two men working together. Have one operator open the ground with a spade and the other place the plant in the hole. Insert the spade again in the ground and press the soil against the roots. 


\section{Cultivation}

Begin cultivation in a new raspberry patch soon after planting. In an established plantation cultivate the land as soon as it can be worked. At no time should cultivation be deeper than four inches, and at any time only sufficiently deep to keep the weeds under control. When it is necessary to clean out the weeds around the plants, use a fork instead of a hoe. Give the plantation a good clean-up with the spring-tooth cultivator and harrow when harvesting is over. A cover crop, such as fall rye, should be sown between the rows for the purpose of replacing the soil organic matter or humus that has been decomposed or burnt up during the period of cultivation. The cover crop may have a secondary beneficial effect of reducing the amount of winter injury by using up soil nutrients and excess moisture, and so causing the raspberry wood to become well ripened.

\section{Mulching}

Under some conditions, mulching the plantation with straw, peat, sawdust, or similar material, may well replace cultivation management. The advantages that may accrue from mulching are:- conservation of moisture with cooler soil, elimination of cultivation, and prevention of soil erosion. However, mulching may cause some delay in the ripening of the fruit since the soil is slower to warm up in the spring. Weed seeds may be introduced with the mulch material and the mulch may not smother all grass or weeds, thus necessitating hand pulling. If sawdust or straw is employed as a mulch material, a decrease in plant growth may occur due to a depression of available nitrogen in the soil unless extra nitrogen is supplied in the form of commercial fertilizer. For every ton of straw or sawdust applied it may be necessary to apply 75 to 100 pounds of ammonium sulphate or its equivalent.

Mulching for raspberries has still not been adequately evaluated but it is worthy of consideration.

\section{Fertilizers}

The wise use of fertilizers increases vigour and yield. Previous to setting out the plants apply barnyard manure at the rate of 15 to 20 tons per acre. Give annual applications thereafter in late fall or early spring. The amount to apply may be judged by the vigour and general health of the plantation.

If barnyard manure is not available, two to three tons of hay or straw per acre may be disked into the soil after harvest. In order that soil nitrogen may not be unduly depressed broadcast 75 pounds of ammonium sulphate or its equivalent per ton of hay or straw before disking.

In the spring apply a 9-5-7 commercial fertilizer at the rate of 700 pounds to the acre or a mixture of 300 pounds of sulphate of ammonia, 180 pounds 20 per cent superphosphate, and 100 pounds muriate of potash before disking in the cover crop.

\section{Pruning}

The value of cutting back red raspberry canes is debatable. It is always well to remember that a severe heading back will reduce the crop materially. In eastern Ontario and Quebec there is generally a little killing back of the tips. This is equivalent to a spring pruning so that further cutting back is not necessary. If the variety is especially tall, a topping given in late fall or early spring may be desirable.

Pinch back purple and black raspberries in the summer. Purples are generally pinched at about 24 to 30 inches and blacks at 18 to 24 inches. This pinching back causes the canes to produce laterals that should be shortened to eight or ten buds in the spring. 
Remove and destroy all the fruiting canes by burning as soon as the crop is harvested. For this work use pruning shears or a V-shaped brush hook. After the third year, considerable thinning out is necessary in the red raspberry plantation. With the hedge-row system each cane requires about forty square inches of space to develop properly, therefore thin the canes to six inches apart. In the case of black and purple raspberries grown in the hill system, leave six or eight canes to each plant.

\section{Trellising}

If it is difficult to keep berries off the ground, trellis the hedge-row. To do this set stout posts at 15- to 30 -foot intervals in the centre of the row. To these attach cross arms about 18 inches long and from 24 to 30 inches above the ground, depending on the height of the canes. String wires along the outside lengths of each row and attach them to the ends of the cross arms.

\section{Harvesting}

The fruit of the raspberry, particularly the red, ripens quickly, soon reaches its highest point of excellence, and deteriorates rapidly. Therefore, make plans well in advance to handle every detail of harvesting and marketing promptly and efficiently. Pint boxes are better than larger sizes for the red varieties, as less crushing of the berries takes place.

\section{Winter Protection}

In some parts of Canada certain varieties of raspberries require winter protection. To assure this, bend down the canes just before winter sets in and hold them down with a little soil on the tips. If the soil is removed from one side of the hill the canes will bend sufficiently without breaking. Have one operator collect the canes in a bunch and press them down with a fork, while another applies sufficient earth to hold them down. The labour cost involved in covering an acre is small. On the prairies the best results are obtained when the canes are entircly covered with soil. If the rows are placed at least eight feet apart much of the work of covering can be done with horses.

\section{BLACKBERRY GULTURE}

In Canada the blackberry is found wild from Newfoundland westward to near the Manitoba boundary and in British Columbia.

Blackberries are grown with varying degrees of success in Ontario and Quebec. The amount of protection they get in winter usually governs the results obtained. At Ottawa there is rarely a good crop of blackberries, as there is not quite enough snow as a rule to protect them well, and the canes are injured. In the Lake Huron district, where there is a heavy fall of snow, blackberries succeed very well. When unprotected by this covering in winter they cannot be grown satisfactorily.

Few blackberries are grown commercially in Quebec, and in Ontario commercial culture is confined mainly to the southwestern section of the province. Blackberries do exceptionally well in British Columbia, and also succeed in parts of the Maritime Provinces.

\section{The Blackberry Plantation}

A blackberry plantation is in full bearing the third season after planting, and will continue to produce profitably for many years if it is well cared for. However, it is usually best to renew the plantation every eight or ten years. 
Site and soil.-One of the best soils for blackberries is a good upland clay loam, and in choosing site and soil provide for (a) an adequate supply of moisture and (b) sufficient plant food. Blackberries ripen in late July or August when the weather is often dry and hot. If there is not enough moisture the fruit will dry up and only a few good berries develop. Upland clay loam is likely to contain sufficient plant food, without too much nitrogen, for favourable development of the crop and ripening of the wood.

Avoid a soil that has an excess of nitrogen. The blackberry grows late in the fall and nitro ren is inclined to induce even later growth with the result that the tender shoots are likely to suffer injury from frost. Bottom land in most places is likely to be rich in nitrogen.

\section{Varieties}

The parts of Canada in which blackberries succeed well are limited to those where the winters are only moderately cold or where the winters are cold but with an abundance of snow for protection.

$$
\begin{aligned}
& \text { Medium hardy-Lowden. } \\
& \text { Medium tender-Eldorado. }
\end{aligned}
$$

\section{Propagation}

The blackberry is one of the easiest fruits to propagate. Use the suckers, which are produced in great numbers, or, if it is desired to propagate a variety even more rapidly than by suckers, root cuttings are the answer. Cut the roots into pieces two or three inches long, either in the fall or in the spring, and plant them in nursery rows about three inches deep for one season. Good plants will be available at the end of the first season if the soil is well cultivated.

\section{Planting}

When to plant.-Plant in the spring if possible and use strong one-yearold suckers. If the blackberries are planted early in the autumn the young plants are likely to start growth, and the new shoots may be injured by the frost. If planted late in the fall the plants do not become properly established before cold weather sets in.

How to plant.-Blackberries require plenty of space to allow for proper development and to afford an opportunity for cultivating and picking. Space the rows not less than eight feet apart with three feet between the plants in the rows. Where the blackberry grows vely vigorously, four feet between the plants is not too much. Plant the Evergreen variety sixteen or more feet apart in the rows.

The quickest way to plant is to open deep furrows eight feet apart. Every three feet in these rows make a hole with a spade and set the plant a little deeper than it grew previously. Press the soil firmly against the roots and plant. If especially fine fruit is desired, set the plants about eight feet apart each way and keep them in hills. This allows cultivation both ways, and a better opportunity for the plants to develop.

\section{Cultivation}

During the first year cultivate the soil well in order to get the plants properly established and procure strong growth early in the season. Blackberries do not ripen until late in the summer, and it is well to continue cultivation until the berries are almost ready to pick. 


\section{Fertilizers}

Apply well rotted barnyard manure to the land at the rate of 10 to 15 tous per acre previous to setting out blackberry plants. Make annual applications thereafter in the early spring or late fall, judging the amount by the vigour of the plants. If barnyard manure is not available, sow cover crops between the lows annually. Supplement these with a complete commercial fertilizer, 9-5-7. at the rate of 400 to 600 pounds per acre.

\section{Pruning}

When the new plants are eighteen inches to two feet in height pinch off the tips. This makes the canes throw out side shoots and prevents them from becoming too tall. At the end of the growing saason, remove all except three or four of the strongest canes.

In the second year pinch back the new shoots when they reach two feet. As they will not attain the same height at the same time, go over the plantation several times. Destroy all suckers. It is important to do this work at the proper time, for if it is done too late the laterals will continue to grow and be injured by winter. During the second season leave five or six of the strongest canes and remove all the rest either during the summer or in the autumn.

Follow this practice every year, removing the canes that have borne fruit as soon after fruiting as it is convenient to do the work. Each spring head back the laterals. The length of lateral to be left will depend on the variety since some kinds set fruit further out on laterals than others. If the fruiting habit of a variety is unknown wait until the flower buds show before heading back the laterals. The length of lateral to leave after pruning will vary considerably, but do not leave more than two feet.

If it is not possible to pinch back the new shoots in the summer-and no pinching is bettel than pinching too late-head back the bushes to three or four feet in height in the spring and head in the laterals as already described.

\section{Harvesting}

Proper harvesting of blackberries is very important. The blackberry, when it is perfectly lipe, is one of the finest fruits, but if it is picked before that stage it is quite unfit for use. Since some varieties become black before they are fully lipe exercise care to make sure that they are harvested only when they are at the peak of excellence.

\section{Winter Protection}

Pinching back in summer tends to keep the bushes lower than they otherwise would be and they are thus less exposed in winter. Give them added protection by bending them over and covering the tips with soil to hold them in place. 'This is, however, very unpleasant work and it scarcely pays if blackberries are grown commercially. To give still more protection, cover the canes with soil, straw, or coarse manure. 


\section{GOOSEBERRY CULTURE}

The gooseberry is a native of Canada and is found growing wild almost to the Arctic Circle. It may be cultivated quite successfully in any province, but thrives best in regions where the summer temperatures are relatively cool.

\section{The Gooseberry Plantation}

Gooseberry bushes will not produce a full crop until the fourth season, although they will often begin to bear during the second year after planting. The plantation will not need to be renewed for many years, if the soil is kept in good condition, properly cultivated, and the bushes kept sprayed and well pruned.

Soil and drainage.-Heavy clay loams that are well drained are the most suitable for gooseberries. The gooseberry is a moisture-loving plant and these soils are usually cool and moist. In dry soils, gooseberries suffer so greatly in times of drought that the foliage often falls off prematurely and the fruit is scalded by the sun. Sandy loams are not suitable for this fruit as the surface of the soil becomes very hot in summer. In general, choose a soil for the gooseberry plantation where a constant supply of water is assured during the growing season.

\section{Varieties}

Clark, Silvia, and Poorman are the best of the commercial varieties. Among the newer introductions Fredonia, Ross, and the thornless variety Captivator (named in 1949) are worthy of extended trial.

Clark. - This is a European type, thought to be a natural hybrid between native and European varieties. The fruit is very large, elliptical, greenishyellow with a copper-red blush when fully ripe, and of good quality. The plants are moderately vigorous, hardy, appear free from mildew, and although none too productive at Ottawa, yield well at the Horticultural Experiment Station, Vineland Station, Ontario. Clark is highly recommended because of its large size, high quality, and freedom from disease.

Fredonia. - This is a very promising gooseberry of the English type originated at the N.Y. State Agricultural Experiment Station, Geneva, N.Y. The berries are large, deep red when ripe, and of good quality. The bushes are vigorous and to date have shown no signs of winter killing. If the bushes prove hardy, Fredonia, because of its desirable fruit characteristics, should become popular in Canada.

Poorman (Houghton $\times$ Downing).-This is a United States introduction originated by Wm. H. Craighead of Brigham City, Utah. Poorman is especially noteworthy because of its vigour and productivity. The plants produce numerous new shoots and are rather dense and spreading in growth. The fruits are large, green at first, later changing to an attractive pinkish-red. The flesh is tender, juicy, sweet when ripe, and of good quality.

Ross.--Recently introduced by the Dominion Forest Nursery station, Indian Head, Saskatchewan, Ross produces berries almost as large as Clark. The bushes are very hardy, vigorous, and productive. The fruits are very large and pale green in colour. Because of its hardiness and berry size, Ross is worthy of extensive trial.

Silvia (parentage unknown).-Originated by Wm. Saunders, London, Ont., this variety was introduced by the Horticultural Division, Central Experimental Farm, Ottawa. The bushes are very hardy, strong, moderately upright 
in habit, and productive. The berries are large, greenish, later becoming more or less covered with dull red, of good flavour and high quality when ripe. This variety is outstanding because of its hardiness, productivity, and the uniformity of its fruits.

New Ottawa Thornless Introductions.-The following thornless gooseberries originated by the Division of Horticulture, Central Experimental Farm, Ottawa, have been very impressive at Ottawa. Although not entirely thornless, the thorns on these five varieties are so short and few that they do not interfere with fruit picking.

Captivator (0-272) (Spinefree $\times$ Clark).-This has been the most impressive of the thornless varieties to date. It is very productive, the berries are about the same size as Poorman, turn red when ripe, are distinctly pear-shaped, have thick skins, and are of good quality. This variety is vigorous, hardy, of upright habit, and suckers freely. There are a few short thorns at the bases of some of the shoots but not enough to be troublesome.

0-261 (Clark $\times$ Spinefree).-The berries are medium in size, elliptical, coppery-led when ripe and of fairly good quality. The bushes are vigorous, hardy, and almost free of spines.

0-271 (Spinefree $\times$ Clark).- The berries are about the same size as Poorman, round to pear-shaped, medium red when ripe, have thick, tough skins and a pleasant, mild, sub-acid flavour. 'The bushes are vigorous, hardy, upright in habit, and the canes are almost thornless. This variety is fairly productive but not so heavy a yielder as Captivator.

0-273 (Spinefree $\times$ Clark).-The berries are medium to above medium in size, pear-shaped, coppery-red when mature, and of good quality. The bushes are vigorous, hardy, and productive. This variety resembles Captivator in berry characteristics but ripens a few days earlier. It is more thorny than the others, but the thorns are short and are not troublesome.

0-274 (Spinefree $\times$ Clark).-This variety is very productive but the fruit is not quite so large as that of Captivator. The berries are oval in shape, turn red when ripe, have medium thick skins and are of good quality. The bushes are vigorous, hardy, sucker freely, have stout branches, and are medium upright in habit of growth. The canes have a few short spines, but not enough to be troublesome.

\section{Propagation}

Gooseberries may be propagated either by layering or from cuttings. The best results are, however, obtained from layering.

Layering.- To propagate by layering prune the bushes severely in the autumn or early in the spring. This will induce a strong growth of young shoots. In July, when these young shoots have made most of their growth, heap the earth around and through the bush. Leave only the tips of the young shoots uncovered. Pack the soil down and throw a covering of loose soil on top to retain moisture better.

Most of the American varieties will be well rooted by autumn. Detach the young plants, set them in nursery rows either in the same fall or the following spring, and allow them to grow in the nursery for one season. English varieties usually take two years to root, and the soil must be left around the bushes during that time. 
Cuttings.-Cuttings of American varieties sometimes give fairly satisfactory results. Make these cuttings six to eight inches or less in length from well ripened wood taken in the autumn after the leaves have dropped, and bury them in the soil over winter. In the spring set them out in nursery rows, planted so that only one or two buds are above the ground.

Both American and English varieties may be propagated from softwood cuttings in a greenhouse, or in a hotbed with bottom heat.

\section{Planting}

When to plant.- - It is usually better to plant in the autumn as gooseberries start to grow early in the spring. Morever, the leaves drop early so that gooseberries may be planted in September and will be in good condition when winter sets in.

How to plant.-Strong one-year-old plants are best for planting, but if they are lacking in vigour use two-year-old plants. Cut them back to from six to twelve inches depending upon their vigour and trim off all broken roots. To give ample room for cultivation set the plants in rows six feet apart and five feet apart in the rows. Plant them somewhat deeper than they stood in the nursery and tramp the soil well about them.

If the plants are of a variety that does not branch naturally, set them so that the lowest branch starts just below the surface of the soil. This develops a bush rather than a tree type of plant.

\section{Cultivation}

Practise shallow cultivation as the roots of the gooseberry grow near the surface, but after planting cultivate thoroughly to keep the weeds well in check. On soils that tend to be dry mulch with straw to retain moisture.

\section{Mulching}

Under some conditions, mulching the plantation with straw, peat, sawdust, or similar material, may well replace cultivation management. The advantages that may accrue from mulching are:-conservation of moisture with cooler soil, elimination of cultivation, and prevention of soil erosion. However, mulching may cause some delay in the ripening of the fruit since the soil is slower to warm up in the spring. Weed seeds may be introduced with the mulch material and the mulch may not smother all grass or weeds, thus necessitating hand pulling. If sawdust or straw is employed as a mulch material a decrease in plant growth may occur because of a depression of available nitrogen in the soil unless extra nitrogen is supplied in the form of commercial fertilizer. For every ton of straw or sawdust applied it may be necessary to apply 75 to 100 pounds of ammonium sulphate or its equivalent.

\section{Fertilizers}

As gooseberries are heavy feeders they need a large amount of plant food. Apply a good application (15 to 20 tons per acre) of well rotted manure yearly in the late autumn or early spring and thoroughly work it into the soil. If barnyard manure is not available, give an annual application of $9-5-7$ complete fertilizer at the rate of 400 to 600 pounds per acre.

\section{Pruning}

The gooseberry makes much more wood than it is desirable to leave, therefore severe pruning is necessary. Prune with a view to retaining only vigorous bearing wood. The fruit is borne on year-old wood and from spurs on older wood 
and as a rule no wood more than three years old should be left. Cut off all branches that touch the ground to allow a better circulation of air, and to keep the fruit off the ground.

When to prune.-The best time to prune gooseberries is in the autumn or early winter. Pruning may be carried out in the spring, but growth starts very early and it is often difficult to get the work done before the buds start to swell.

How to prune.-In America the gooseberry is usually grown in the bush form. Shape the bush by leaving a few of the strongest shoots regularly distributed to make an open head. Five or six of these shoots are quite sufficient to retain at first. Cut off the weakest young shoots at the ground. As the bush gets older allow new shoots to grow to take the place of older ones. Cut away all the young shoots not required for fruiting or to take the place of older branches. Head back the side shoots from older branches or cut them out altogether to maintain a fairly open head. This makes it easy to pick the fruit and yet leaves sufficient wood to produce a good crop and enough foliage to protect the fruit from sun scalding.

\section{GURRANT GULTURE}

The currant bush is host plant for the white pine blister rust, which is a very selious disease in sections where the five-needled pine is grown extensively for timber. Currants, therefore, should not be planted in districts where the white pine is considered of commercial importance. They can, however, be grown in districts where the white pine is not present or is of no economic importance. In such districts timely and careful spraying should be practised.

Currants are natives of cool, moist, northern climates. They are very hardy, and will withstand extremely low temperatures if windbreaks are provided. Black currants have particularly high nutritive value, being particularly rich in vitamin $\mathrm{C}$. They thrive well under the climatic conditions that prevail in Central Canada.

\section{The Currant Plantation}

The life of a currant plantation is at least fifteen years. The number of years it will continue in good bearing condition depends upon the location, soil, and the care that it receives.

Site.- Select a site with a gradual slope to give good surface and air drainage. Currants will not do well on sites where water stands for any length of time during any part of the year. If possible choose a northern exposure, as in such a situation the currants will not be likely to suffer in a dry time. An abundant and continuous supply of moisture is one of the principal requirements and for this reason a good supply of humus in the soil is important.

Soil. - The soil should be cool as the currant is a moisture-loving bush. The ideal type for the cultivation of currants is a rich, deeply worked clay loam. If such a soil is well supplied with humus, cool, moist, and well drained it will vield up to four tons per acre of black currants and even heavier crops of red and white currants. The roots of the currant are near the surface, hence if the soil is hot and dry, the currant crop will suffer. Light sandy soils and heavy soils that tend to bake are also undesirable.

\section{Varieties}

Over a period of some forty years, the Central Experimental Farm at Ottawa has tested practically every black currant variety under name, including the famous English varieties. In making varietal recommendations, however, sole reliance has not been placed on their performance at Ottawa, for most 
varieties have been under test on Dominion Experimental Stations from the Atlantic to the Pacific. The following varieties of black currants are considered to be the best for commercial planting in Central Canada:-Magnus, Saunders, Kerry, and Climax. Boskoop Giant, because of its large size and high quality, is recommended for home use only. Magnus, Kerry, and Climax are recommended by ten of the Dominion Experimental Stations for commercial planting in their immediate districts. Saunders is recommended by nine stations. It is evident, therefore, that these varieties do well under a wide range of climatic conditions.

At Ottawa in 1943 Saunders produced ovel foul tons of black currants to the acre, Kerry about the same, Magnus three and three-quarter tons and Climax about four and one-half tons. All are therefore heavy yielding varieties. Magnus is preferred because of its evenness of ripening, since this makes it possible to harvest the entire crop at one picking and thus keep picking costs down to the minimum. The cost of picking is probably the most expensive item in connection with currant cultivation. At present it costs about five cents a pound to harvest this fruit.

Fays Prolific, Cherry, and Perfection are the red currant varieties commonly planted in the past. Two recent introductions Stephens No. 9 and Red Lake are so superior to the varieties commonly grown that it is recommended that all red currant plantings in the future should be of these varieties only. Cascade, another new red variety, also offers real promise.

There is no marked demand for white currants, but where a few bushes are wanted for home use White Dutch is preferred. White Grape is also a good variet $\mathrm{y}$.

\section{Black Currants}

Bosmoop Giant.-This variety is outstanding because of its large size and high quality. The bushes are some what sprawling in habit, medium in vigour, and low yielding. The berries are very large, uniform, and of excellent quality. Boskoop Giant lacks productiveness for commercial use.

Clmax.-This is a vigorous, productive variety of good quality. The bushes are sturdy and erect. The berries are medium to large, and uniform.

IERRY. - The fruit and plant characteristics of this variety are very similar to those of Saunders. The bushes are upright, vigorous, and productive. The berries are large and of good quality but not so uniform in size as Magnus and Saunders.

MAGrus.-This variety is particularly noteworthy because its fruit ripens evenly, making it possible to harvest the crop in one picking. The bushes are upright in habit, medium vigorous, and productive. The berries are large, uniform, and of good quality.

SAUNDERS. - This is a vigorous variety that thrives well under a wide range of soil and climatic conditions. The bushes are erect, vigorous, and productive. The berries are large, uniform, of good quality, and ripen fairly evenly.

\section{Red Currants}

Cascade (Minn. No. 70).-This is an open pollinated seedling of Diploma. The bush is medium in vigour, fairly erect and productive. The clusters are above medium in size, and compact with fairly long stems. The berries are very large, attractive, dark red, pleasant sub-acid in flavour and of very good quality. The fruit of Cascade ripens about a week earlier than Red Lake and the berries are larger but the clusters are not so long. Cascade is worthy of extended trial. 
RED LAKE. - This is a Minnesota origination of unknown parentage and is the best red currant so far introduced from the United States. Its clusters are a little longer than those of Stephens No. 9; otherwise the two varieties are similar, both producing very large, glossy, light red berries of excellent quality that may be eaten out of hand. The bushes are vigorous and productive but somewhat sprawling.

Stephens No. 9.-This variety was originated by C. L. Stephens, Orillia, Ont., and distributed by the Central Experimental Farm, Ottawa. The bushes are vigorous, somewhat spreading, and productive. The clusters are of medium length, not so long as Red Lake but compact. The berries are very large, attractive bright red in colour, sub-acid in flavour, of excellent quality, and can be used for dessert purposes. Stephens No. 9 is on a par with Red Lake, and both varieties are vastly superior to the varieties commonly in use.

\section{White Currants}

White Dutch.- This is undoubtedly the best of the white fruited varieties, mainly because of its excellent quality. The bushes are vigorous, upright, and attain fair size. The berries are of medium size, yellowish-white, tender and translucent, and are borne in fairly compact bunches. The flesh is tender, juicy, mildly sub-acid, and of very high quality.

White Grape.-This is one of the best of the commonly grown white varieties. The bushes are vigorous, upright, and productive. The berries are medium in size, yellowish-white, translucent, tender, and are borne in mediumsized, fairly compact clusters. The quality is good. The berries are not so uniform and the cluster not so compact as White Dutch, nevertheless White Grape is a heavy yielder of high quality fruit.

\section{Propagation}

Usually one may obtain plants of the varieties desired from reliable nurserymen at a reasonable cost, and this is a satisfactory way to obtain them for the home garden or for commercial planting. It is also possible to propagate them by means of cuttings or layers. Since currants root readily from cuttings, they are propagated almost entirely by this method.

Making the cuttings.-The best time to make the cuttings is in the autumn after the leaves have dropped. Currants begin to grow very early in the spring and once the buds have swollen they cannot be rooted successfully. Make the cuttings from vigorous shoots of the current season's growth as follows: (a) cut the shoots into pieces eight to ten inches long (b) make a square cut at the base of the cutting below the bottom bud and (c) leave at least one-half inch of wood above the top bud.

Care of the cuttings.-Prepare furrows in a rich, well prepared and well drained soil three feet apart and deep enough that the top bud or not more than two buds will be above the ground. Plant the cuttings as soon as they are taken. Place them about six inches apart on the smooth ide of the furrows, and tramp the soil well about them. If the cuttings cannot be planted at once bury them upside down in sand or store them until spring. The storage cellar should be cool enough to keep them dormant and moist enough to prevent drying. It should not, however, be so moist as to cause mould to develop on them. 


\section{Planting}

When to plant.-Currants start growth very early in the spring and for this reason autumn planting is advisable. Since currant plants lose their leaves early they can be transplanted in the early fall. This enables the roots to become established in the soil before winter sets in. If spring planting is unavoidable, plough and manure the land in the fall and make it ready for early spring planting.

How to plant. - Strong one-year-old plants are best for planting but twoyear-old plants are better than poorly-rooted yearlings. Since currants make strong growth, give them plenty of space. The distance between rows depends mainly on the type of cultivator that will be used, six feet being required for a one-horse cultivator. Set the plants five feet apart in the row, and at least an inch deeper than they were in the nursery. Tramp the soil well about the young plants when they are set out. It is better to plant a little deeper than is necessary than to plant too shallow.

\section{Cultivation}

When the plants are young cultivate fairly deeply in the middle of the row. This tends to make the roots grow somewhat deeper than they otherwise would. As the roots begin to extend across the rows practise shallow cultivation, since many of the roots are quite close to the surface. In general, cultivate only enough to keep the weeds in check.

\section{Mulching}

Under some conditions, mulching the plantation with straw, peat, sawdust, or similar material may well replace cultivation management. The advantages which may accrue from mulching are:-conservation of moisture with cooler soil, elimination of cultivation, and prevention of soil erosion. However, mulching may cause some delay in the ripening of the fruit since the soil is slower to warm up in the spring. Weed seeds may be introduced with the mulch material and the mulch may not smother all grass or weeds, thus necessitating hand pulling. If sawdust or straw is employed as a mulch material a decrease in plant growth may occur due to a depression of available nitrogen in the soil unless extra nitrogen is supplied in the form of commercial fertilizer. For every ton of straw or sawdust applied it may be necessary to apply 75 to 100 pounds of ammonium sulphate or its equivalent.

\section{Fertilizers}

Currants are heavy feeders and should be supplied with a large amount of plant food. Unlike many other fruits, they are not subject to winter injury if too rank growth is made. However, they do not grow wood at the expense of fruit. It is therefore safe to apply liberal amounts of nitrogen, especially as the plantation gets older. There is little danger of giving currants too much fertilizer; too frequently their nutritional requirements are not adequately met.

Apply barnyard and poultry manure at the rate of 15 to 20 tons per acre as an initial pre-planting application. Use the same amount annually thereafter during the life of the plantation. Apply the fertilizer in autumn and winter, or, if well rotted, in the early spring. If manure is unobtainable, grow green manure crops in advance of planting, and supplement these at the time of planting and each year thereafter with a 9-5-7 complete fertilizer at the rate of 400 to 600 pounds per acre. Use straw mulch as required to maintain humus. 


\section{Pruning}

Prune during the dormant season, either following the dropping of the leaves in the autumn or in the early spring before growth starts. In pruning varieties of spreading growth, remove the outer and lower shoots. Trim varieties having an erect habit of growth by the removal of the central shoots.

Black currants.-The black currant bears most of its fruit on wood of the previous season's growth, therefore prune with a view to leaving a plentiful supply of new wood. During the first season after planting prune merely to shape the bush. After the second year pruning is, in effect, a process of renewal.

Red and white currants.-Red and white currants produce the bulk of their fruit on spurs on the two- and three-year-old wood. Therefore, the second year after planting remove the weaker shoots leaving six to eight strong shoots accord ng to the vigour of the bush. At the end of the third year leave four or five two-year-old shoots; and the fourth year after planting retain about three shoots each of three-year-old, two-year-old and one-year-old wood. During the following years remove all branches more than three years of age that have passed the heavy bearing period, and leave enough one-year-old shoots to take their places.

\section{BOYSENBERRY GULTURE}

The Boysenberry is an improved Loganberry and, like its parent, is a warm climate crop. It can be grown in the colder regions of Ontario, such as the Ottawa district, but it does not produce enough fruit to make it commercially profitable. The Boysenberry is usually grown for canning. It does not make a satisfactory product for the fresh fruit trade.

The plants are set in rows about seven or eight feet apart, with the plants about two feet apart in the rows. They are grown in the hedge-row system, using a two-wire trellis. The fruiting vines are tied to the trellis, and, when harvesting has been completed, they are removed by cutting them back close to the ground. In most parts of eastern Ontario and Quebec, the new shoots that have been allowed to grow along the ground are protected during the winter months by covering them with soil just before the ground freezes. In the early spring when the buds commence to swell the soil is removed and the vines are put up on the wires.

The best fertilizer is well rotted barnyard manure applied at the rate of about 10 pounds per plant. If this is not available, a 9-5-7 commercial fertilizer may be used at the rate of three or four pounds per plant. 


\section{EXPERIMENTAL FARMS SERVICE}

Director: E. S. Archibald, B.A., B.S.A., LL.D., D.Se.

Acting Director: E. S. Hopkins, B.S.A., M.Sc., Ph.D.

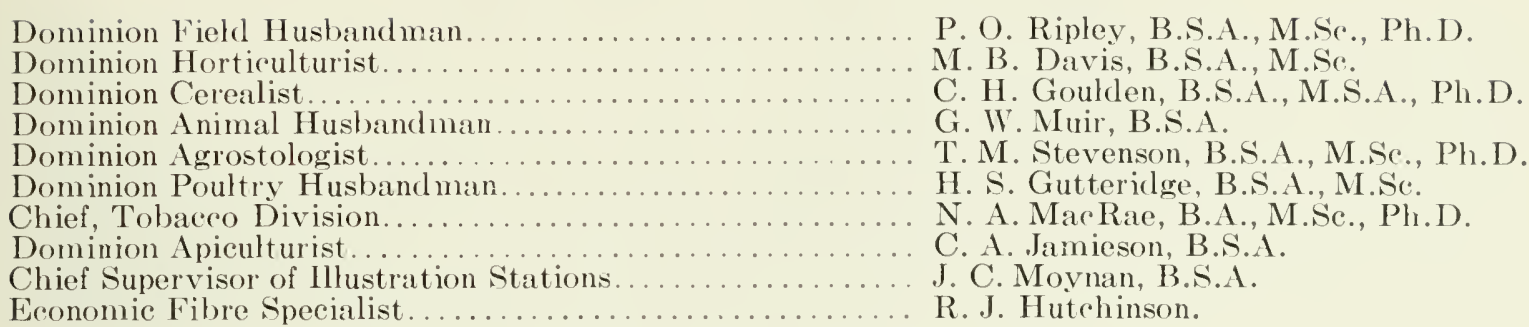

PRINCE EDWARD ISLAND

Superintendent, Experimental Station, Charlottetown: R. C. Parent, B.S.A., M.Sc.

Superintendent, Experim ntal Fox Ranch, Summerside: C. K. Gunn, B.Sc., M.Sc., Ph.D.

NOVA SCOTIA

Superintendent, Experimental Farm, Nappan: W. W. Baird, B.S.A.

Superintendent, Experimental Station, Kentville: A. Kelsall, B.S.A.

\section{NEW BRUNSWICK}

Superintendent, Experimental Station, Fredericton: S. A. Hilton, B.S.A., M.S.A.

\section{QUEBEC}

Superintendent, Experimental Station, Lennoxville: J. A. Ste. Marie, B.S.A.

Superintendent, Experimental Station, Ste. Anne de la Pocatiere: J. R. Pelletier, B.S.A., M.A., M.Sc.

Superintendent, Experimental Station, L'Assomption: R. Bordeleau, B.S.A.

Superintendent, Experimental Station, Normandin: A. Belzile, B.S.A.

Officer-in-Charge, Experimental Substation, Ste. Clothilde: F. S. Browne, B.S.A.

Central Fxperimental Farm, Ottawa.

ONTARIO

Superintendent, Experimental Station, Kapuskasing: F. X. Gosselin, B.S.A.

Superintendent, Experimental Station, Harrow: II. F. Murwin, B.S.A.

Officer-in-Charge, Experimental Substation, Delhi: L. S. Vickerv, B.S.A., M.Sr.

Officer-in-Charge, Experimental Substation, Smith field: D. S. Blair, B.S.A., M.Sc.

\section{MANITOBA}

Superintendent, Experimental Farm, Brandon: R. M. Hopper, B.S.A., M.Sc.

Superintendent, Experimental Station, Morden: W. R. Leshie, B.S.A.

Officer-in-Charge, Pilot Flax Mill, Portage la Prairie: E. M. Mackey, I3.S.A.

\section{SASKATCHEWAN}

Superintendent, Experimental Farm, Indian Head: J. G. Davidson, B.A., B.S.A., M.S.A.

Superintendent, Experimental Station, Scott: G. D. Matthews, B.S.A.

Superintendent, Experimental Station, Swift Current: G. N. Denike, B.S.A.

Superintendent, Experimental Station, Melfort: H. E. Wilson, B.S.A.

Superintendent, Experimental Substation, Regina: J. R. Foster, B.S.A.

Superintendent, Forest Nursery Station, Indian Head: John Walker, B.S r., M.S.

Superintendent, Forest Nursery Station, Sutherland: W. L. Kerr, B.S.A., M.Sc.

\section{ALBERTA}

Superintendent, Experimental Station, Lacombe: G. E. DeLong, B.S. A. M.Sc. Superintendent, Experimental Station, Lethbriclge: A. E. Palmer, B.Sc., M.S.c. Superintendent, Experimental Station, Beaverlodge: E. C. Stacey, B.A., MI.Se. Officer-in-Charge, Range Experiment Station, Manyberries: H. F. Peters, B.S.A. Officer-in-Charge, Experimental Substation, Fort Vermilion: V. J. Lowe.

\section{BRITISH COLUMBIA}

Superintendent, Experimental Farm, Agassiz: W. H. Hicks, B.S.A.

Superintendent, Experimental Station, Summerland: R. C. Palmer, B.S.A., M.Sc., D.Sc.

Superintendent, Experimental Station, Prince George: F. V. Hutton, B.S.A.

Superintendent, Experimental Station, Saanichton: J. J. Woorls, B.S.A. M.S.A.

Superintendent, Experimental Substation, Smithers: W. T. Burns, B.S.A., M.Sc.

Officer-in-Charge, Range Experimental Station, Kamloops: T. G. Willis, B.S.A., M.S.A.

\section{YUKON AND NORTHWEST TERRITORIES}

Officer-in-Charge, Experimental Substation, Whitehorse, X.T.: J. W. Abbott.

Officer-in-Charge, Experimental Substation, Fort Simpson, N.W.T.: J. A. Gilbey, B.S.A., M.se. 
OTTAWA
EDMOND CLOUTIER, C.M.G., B.A., L.Ph.,
INGS PRINTER AND CONROLER OF STATIONEY
1950 